\title{
The Impacts of Brexit on China
}

\author{
Lishan Zhang \\ School of Economics and Management \\ Tongji University \\ Shanghai, China \\ lishanzhang3@hotmail.com
}

\begin{abstract}
As for the Black swan incidents during 2016, one thing that can't be ignored should be Brexit. Meanwhile, in the current period of globalization and multilateralism, another country is also experiencing great changes and transformations: China is an emerging giant. It is certain that such a global event, Brexit, is and will be producing impacts on China, in terms of economy, trade, policy and diplomacy. It is said that China's role in the post-Brexit world and with a Trump administration in the US will be uncomfortable and powerful at the same time. And this paper is going to analyze these influences from three aspects combined with the available data before and after Brexit.
\end{abstract}

\section{Keywords-Brexit; China; Sino-EU; Sino-Britain}

\section{IMPACTS ON SINO-EU RELATION}

The EU has been a way critical partner and the largest trading partner for China (Wong, 2017) [1]. To develop the relations with the EU well will contribute to implementing China's four major strategies which includes Go Global Strategy, China Western Development Strategy and Talent Strategy. Indeed, China has worked hard to develop economic relations with the EU. There is a rise in China's FDI in Europe from 2000. But the Eu's attitude is not that satisfying for China. And in 2012, the EU only holds $2 \%$ of its FDI in China.

\section{A. "Marekt Status" Status}

China and the EU have some fundamental differences. China is a country with dual identities, combining a developing country reality with the power ambitions of a great global power. This has created issue-oriented national interests, which can easily conflict with the type of value-based relationship most preferred by the EU. The EU prefers that international politics be organized under a rule-based system, whereas China holds a Hobbesian view on power, which is all about absolute sovereignty, stability and control. It is therefore not surprising that Beijing's current EU policy has largely failed to overcome two obstacles: obtaining market economy status and lifting the arms embargo.

For the first obstacle, China's initial plan was to have the UK as a strong advocate in the debate on "market economy" status. It is also crucial that the EU grants China "market economy" status in order to signal political recognition of the CPP (Yu, 2017) [2]. It is notable that President Xi Jinping once openly voiced the preference that the UK remains in the UK. But Brexit strikes violently China's strategy. If the EU grants China the "market economy" status, some of the China-EU trade restrictions would be lifted. Now it's unlikely that the EU would do that and China has lost a critical bridge with Europe. This may be the most severe result of Brexit in terms of SinoEU relation. And now China needs to come up with another new approach to strengthen cooperation with the EU, which means that the efforts by China will be greatly reduced and some of the efforts turn to sunken costs.

\section{B. Emerging Opportunities}

But what comes with changes is opportunity. From the EU's point of view, the Brexit is believed to weaken its power and has impact on the internal structure. This is an opportunity for China and Sino-EU relation.

Economically speaking, the economy recession and the vacancy in internal trade in Europe now has created more negotiation space and re-balanced the bargaining power for China and the EU. The EU now need reconsider its relation with China and enhance its understanding of Chinese government in order to develop long-term mutually beneficial relations. For China, to get the "market economy" status admission from the EU, it's necessary to review and optimize its market structure or trade policies. It's clear what the EU needs from China. According to the official website of EU, China is the EU's biggest source of imports and its secondbiggest exports market. And in the future, the EU still needs China to continue market reform, open up services and public procurement. This is going to help China to some extent in turn China is already in the biggest multilateral global organization WTO, and it won't cease to cooperate with the biggest multilateral regional organization, EU. Also, among the several types of financial flows, China has mainly and often taken two of them, equity and FDI. Now China may alternatively consider loans and bonds to strengthen the financial relation.

As a result, a more strong relation between the two may be formed and this will influence the USA's development and promote multilateralism globally. 


\section{IMPACTS ON SINO-UK RELATION}

\section{A. Trade and Business}

Britain's leaders have enthusiastically embraced China and the dawning of a "golden time" in Sino-British relations takes on new meaning (Morris, 2015) [3]. According to David Davis's List of targets ranked by priority, China ranks first, which indicates that the UK attaches importance to the business relationship with China. And Hong Kong is also in the "High Priority" regions and this means that Chinese regions totally take half of the places in the highest priority class. Hong Kong's trade system is relatively independent and differs from mainland China; it's still true that Hong Kong is subject to China's national policy and trade restrictions. Although "golden age" was put forward before Brexit, Prime Minister Theresa May again emphasized the word in the 2016 G20 Hangzhou Summit to show UK's willingness to further develop the relation with China. On the other hand, the UK is also an important partner for China. Data has that during 2015, exports to the UK took up to $16.7 \%$ of the total exports to EU from China. Imports from the UK were $9 \%$ of the total amount from the EU to China. So now the UK's future policy and China's reactions to Brexit are of vital significance.

It is anticipated by Welfens (2017) that we cannot entirely rule out the possibility that, through sophisticated and decisive leadership by the British government, the UK could achieve good results relatively quickly, that is by 2020/21[4]. If the Eurozone is not capable of tackling its problems by means of intelligent and sustainable reforms, then it is sure to fall behind the UK in terms of growth in the longer run. In turn, that will increase the incentive for non-Euro countries to rather align themselves with the UK than with EU. The UK may also remain on a pragmatic course of engaged economic cooperation with China. But in fact it's popularly believed in the west that Brexit is an impulsive and accidental incident that will do Britain more harm than good. PwC even pessimistically predicted that the UK will rank 10th in the world's largest economy in 2050. Even the Chancellor Philip Hammond says "Britain is the world's sixth largest economy" in Nov 23, 2017, which implies that the government admits that UK officially falls out the world's top five economies [5]. And so far since June, 2016, there has not been any very remarkable or effective policies established by the UK. Meanwhile it can't be ignored that after Brexit, the UK will not be fully bound by EU laws. The UK may have more freedom to conduct international trade and foreign economic relations. This might bring about benefits to future UK-China cooperation (Wong, 2017) [1]. After all, it is up to the UK itself how to develop in the coming days.

And I believe it's under uncertainty whether the UK can gain success on its own and the EU will be in a losing place. So it's likely that the UK is gradually becoming unattractive for Chinese investors at least in the short run.

What's the possibility from China? As mentioned above, the Chinese government's strategy to have the UK as its access to the whole EU is doom to fail if Brexit is implemented. In reality, before Brexit, there have been a lot of steps taken for the strategy. For example, many Chinese-funded enterprises regard the UK as a bridge to Europe market and they invested in the UK's financial projects and infrastructure projects. Plus, they set up R\&D Centers in London. And they also undertook acquisitions of the British company or British brands. The UK is indispensable in those M\&As. Most commonly, they founded headquarters in London to run business in the whole Europe. There is risk for global production that is from government and politics, and now the Brexit disrupts these companies' plan.

Brexit absolutely affects Chinese enterprises' development both in the UK and in the Europe. It's very possible that these companies will reduce investment projects in the UK. In the meantime, their trade, financial services and staff flow with EU will encounter more obstacles. All these will force Chinese companies to change their international operation strategies, which is sure to influence the UK economy. But another possibility had arose, that is "acquisition oriented" Chinese investors want to take the advantage of the post-Brexit plunge in the value of the Pound Sterling to look for bargains in the UK's property and business sectors(Lim,2016)[6]. But I think this is only a short-run phenomenon just like other short-term fluctuation in economy.

\section{B. Impacts on Population Flow}

For Chinese students, the Brexit would make one of the most popular study-abroad destinations, the UK, less attractive since it no longer has an "EU background" behind. This prediction is often reported in Chinese media. In fact, from the real data, there has been an increasing trend in the number of students (excluding short-term students) that apply for the UK visa and get granted. But I can't find an apparent decrease after the Brexit. The decline at the end of the year and the rise in the third quarter seem to be a regular pattern for every year.

Overall speaking, according to UK's largest independent producer of official statistics and the recognized national statistical institute of the UK, the total visa applicants from China can show Chinese citizens' attitude toward going to the UK. And the trend is still on the increase and the number in 2017 Q1 is even greater than 100,000, which is indeed far higher than the previous years'. Honestly speaking, which country to go to and whether to go to the UK is influenced by a great deal of factors. From the national level, I believe it is still uncertain how the population flow will change. After all the Brexit won't change the fact that the UK has many job opportunities and abundant famous tourist sites and first-class academic institutions.

\section{Impacts on Scientific Collaboration}

In addition, scientific collaboration may also be affected negatively. Yang, Flower \& Huang (2016) estimated that Brexit threatens to undermine the UK's scientific relationships with nations outside the EU [7]. The UK would need to invest more to maintain its valuable collaboration with China. Also under threat will be British scientist' participation in China's projects with EU, such as its Five-hundred-meter Aperture Spherical Telescope, due to be completed in 2016. Scientific and academic projects are certain to be influenced by political changes that the Brexit brought. And thus, along with changes in international trade with China and other countries, economic and industrial changes may result from this. But this should be 
viewed in a longer run and we can't draw a conclusion in a hurry right now.

But we have confidence to say that, after Brexit, the UK will spend more to maintain and develop scientific collaborations that were originally between the EU and China. Meanwhile, China may find it harder or more costly to have new scientific collaborations with the UK and this may cause China more hesitant and unwilling.

\section{Two Real Examples}

As for the Sino-British relations in reality since Brexit, one example is the delayed approval of the Hinkley Point $\mathrm{C}$ nuclear project. Yu (2017) thinks that it is an immediate consequence of changes in the British government after the Brexit referendum [2]. But for Chinese decision-makers, who see it as "a test of mutual trust" in the so-called Golden Age of SinoBritish relations. And lately it is reported by Xinhua News Agency that Xiaoming Liu, the Chinese Ambassador to Britain, attended the 19th Plenary Session of the CPC Congress in the British Parliament. He expressed that the UK and China should further develop the Golden Age and should collaborate more. I believe that although the Brexit has brought about many unexpected changes, it's important and meaningful for both the UK and China to develop diplomatic relations.

\section{IMPACTS ON RMB AND OBOR}

\section{A. Impacts on $R M B$}

Among all the impacts, the impact on currency, China's Renminbi (RMB) should be concerned about. In recent years, London has made great efforts to promote the construction of RMB offshore market. The Chinese Ministry of Finance also issued RMB treasury bonds in London. The Central Bank of China and the UK renewed bilateral currency swap agreements and expanded the scale of exchanges. Besides, the People's Bank of China issued 5 billion yuan of central bank bills in London. London has become the second largest offshore RMB clearing center after Hong Kong. However, due to Brexit, the monetary dividend will no longer exist for China and the costs from promoting RMB in Europe increased drastically. RMB internationalization steps are also disrupted. At present London's status as one of the top financial centers in the world has been challenged. This will have negative impacts on the internationalization of the RMB and the "going global" strategy of Chinese capital. As a result, China's financial institutions need to consider Paris, Frankfurt, Luxembourg and other places and need to pay some adjustment costs.

Another result we should pay attention to is RMB's exchange rate change. According to Wind Information (China), the CFETS RMB exchange rate index only slightly depreciated $0.19 \%$ during the 5 days after Jun 24, 2016. This $0.19 \%$ was much smaller than many other non-dollar currencies. Meanwhile, this depreciation didn't result in market panic in China of buying foreign exchange. This indicates that market players behave more rationally and they recognize that the short-term exchange rate fluctuation was because of temporary external shocks instead of fundamentals of change. Till now we can't find any significant change in trend of RMB before and after the Brexit.

\section{B. OBOR(One Belt One Road Initiative)}

Another impact on China we need to take into consideration is on OBOR. OBOR covers some regions in Europe and Brexit also influences the implementation and results of the strategy. But in fact, so far there haven't been rich research results of Brexit and OBOR. And here I will mainly introduce a paper focused on OBOR and Brexit based on the GTAP model. In this paper, Wang et al. (2017) use tariffs as impact variables and make two different assumptions on tariff rates [8]. In the end, they find similar results under the two assumptions and draw several conclusions as below.

Firstly, the macroeconomic indicators of China and other non-EU countries along the Belt and Road tend to increase, but for the UK and EU they seem to decline.

Secondly, the Brexit creates opportunities for the development of labor-intensive industries in the countries along the Belt and Road. Thirdly, the trade transfer effect resulting from the Brexit will increase the trade between China and other countries related to OBOR. I believe these conclusions are informative for China. They suggest that China should take different cooperation policies according to different countries as the Brexit has differed impacts on them. And the rise in output of non-EU countries' labor-intensive industries can offer investment chances for China's traditional laborintensive industries companies. To sum up, the Brexit would benefit China and other "One Belt One Road" members and harm both UK and EU and even hinder them from participating in OBOR strategy. Therefore, China ought to pay close attention to the economic downturns of the UK and the EU and take the chance to promote the trade and investment cooperation with other OBOR-related countries.

\section{CONCLUSION}

All in all, the Brexit does not mean the European economic integration reverses. Although it may cause some ripple in the financial markets, the overall impact is limited. However, due to the complexity of the Brexit process and the negotiation, which may take years, the full impact of Brexit on China and on the rest of the world, will gradually unfold.

Practically speaking, how Brexit will truly impact China and China's relations with other countries still depend on what measures the UK takes next and how China reacts. But it's for sure that Brexit presents quite a new political and economic image for the UK, the EU and China. And all the three need to reconsider how to achieve greater growth in this relatively new environment. Also, all three sides should embrace the challenge and are meant to seize this opportunity to make more appropriate international policies and adjust strategies outward to obtain better development. 


\section{REFERENCES}

[1] Wong P.K. (2017) Destined Statecraft: Eurasian Small Power Politics and Strategic Cultures in Geopolitical Shifts, Springer, Singapore.

[2] Yu J. (2017) After Brexit: Risks and Opportunities to EU - China Relations. Global Policy8 (54), 109-114.

[3] Morris I. (2015) The Golden Age of Sino-British Relations Is Now. Retrieved from https://worldview.stratfor.com/article/golden-age-sinobritish-relations-now on 3 December 2017.

[4] Welfens P.J.J. (2017) An Accidental Brexit: New EU and Transatlantic Economic Perspectives, Springer, Cham.

[5] Cox J. (2017) UK officially falls out of world's top five economies, Government Admits. Retrieved http://www.independent.co.uk/news/business/news/uk-world-top-fiveeconomy-philip-hammond-budget-economic-forecast-brexit-euwithdrawal-a8071046.html on 3rd December 2017.

[6] Lim A.C.H. (2016) How Concerned Should China Be About Brexit? Analysis. Retrieved from http://www.eurasiareview.com/27062016how-concerned-should-china-be-about-brexit-analysis/ on 3 December 2017.

[7] Yang H., Flower R.J. \& Huang X. (2016) Fellowships: Brexit threatens China collaboration. Nature537 (7619), 167.

[8] Wang Y., Zhang X. \& Zhang E. (2017) How will "Britain's Brexit" affect China's "One Belt and One Road" strategy - based on the analysis of the GTAP model. International Economics and Trade Research33 (5) 29-39. 